\title{
PRODUCTIVITY \\ IMPLICATIONS OF CHANGING \\ EMPLOYER ATTITUDES AND STRATEGIES
}

\author{
Barry Foster ${ }^{1} \&$ Erling Rasmussen ${ }^{2}$ \\ ${ }^{1}$ Massey University, \\ Palmerston North, New Zealand \\ ${ }^{2}$ Auckland University of Technology, \\ Auckland, New Zealand
}

\begin{abstract}
The paper discusses two debates; the rise of individualism in employment relations and the role of employers attidudes and strategies in this shift. Secondly the affect this is having on achieving a high-wage high skills economy. The methodology for this paper used three surveys providing a national coverage of private sector organisations employing ten or more staff. These were undertaken using a cross-sectional design where the surveys matched the sample demographics used by previous New Zealand studies. Semi-structured interviews were also carried out. The main findings are that the New Zealand 'experiment' in employment relations that has been carried out over the last 2-3 decades has not produced the high productivity growth that was intended by its designers.
\end{abstract}

\section{Introduction}

This paper connects two debates which are often discussed separately. First, it discusses the rise of individualism in employment relations and the role that employer attitudes and strategies has played in this shift. Second, the paper overviews the economic and social implications of the rise in individualism and, in particular, how this raises doubts whether a high-wage, high skills economy can be achieved. While the paper is concerned with comparatively relevant theoretical explanations, issues and trends, it takes its empirical starting points in New Zealand surveys and analyses.

While several explanatory factors have been associated with the decline in collective bargaining this paper focuses on the role of employer attitudes and strategies as a key explanatory factor. This has

also been aligned with - as proposed in the Strategic Choice Theory - a more active role of management/employers in influencing and framing the employment relations agenda (Kochan, McKersie and Cappelli 1984).

In investigating a shift to individualism in employment relations New Zealand, a national survey of firms employing 10 or more staff was conducted (Foster et al. 2009a, 2009b). Overall, the survey found that employers have little interest in collective bargaining. However, there are two distinct groups amongst employers: if employers are involved in collective bargaining they have a more relaxed and positive approach to collective bargaining, as opposed to employers who are not involved. With a strong employer preference for individual bargaining, the future of collective bargaining in New Zealand looks grim. Furthermore, the leading employer confederation - Business New Zealand - has been opposed to a development of industry-level collective bargaining. It has also voiced its opposition to employment relations reforms, which have favoured collective bargaining and increased statutory employment minima (Burton 2004 and 2010, Foster and Rasmussen 2010).

While the rise in individualism is clearly aligned with employer preferences it may also raise serious obstacles for particular approaches to achieving a high-wage, highskill economy (McLaughlin 2010). In evaluating these obstacles the so-called New Zealand 'experiment' is an appropriate example since the recent employment relations have covered two different approaches: one of the most deregulatory public policy approaches to employment relations amongst OECD countries has been followed in the new millennium by a public policy approach inspired by European 'social democracy' understanding (Haworth 2004).

Unfortunately, these attempts have failed - for different reasons - to move the New Zealand economy onto a high-wage, high-skill path. In particular, the New Zealand 'experiment' has shown that there are several issues with pursuing a deregulatory approach to employment relations. These issues have included low productivity, low wages and employment conditions, growing social inequities, limited investments in infrastructure and upskilling (Dalziel and Lattimore 1999). Subsequently, 
the economy has struggled to overcome the fallout from these issues in the new millennium (Rasmussen 2009).

Still, the 'social democracy' approach has also had limited success and it assumes either strong collectivism or other 'functional equivalents' which can ensure industry solutions and decent employment standards across the economy. However, the rise in individualism has undermined the role of collectivism and, thus, some kind of 'functional equivalents' is necessary to pursue this reform path. In most cases, legally extended employment standards, including higher statutory minima, would be an obvious option. This would probably raise political opposition since employers are often waging war on statutory minima increases in the name of 'flexibility' and 'affordable labour costs'.

On that background, the 'low road' can easily be the preferred option at least for significant section of the labour market. This has clearly been an issue in many Anglo-American countries with the USA being the prime exponent. Still, it has also been questioned whether this will become the dominant scenario as some commentators have debated whether ILO's decent work agenda and establishing international labour standards have gained traction (Haworth, Hughes and Wilkinson 2005, Standing 2008). There can also be pointed to that many OECD countries have witnessed the introduction of more comprehensive statutory minima and improved individual employee rights in recent years. Thus, 'the jury is still out' and this makes the debate of path-breaking changes to employment relations and their economic and social impacts so fascinating.

\section{The rise in individualism}

New Zealand employment relations has been in turmoil for at least the last 25 years. It has witnessed major changes in the 1980s, the 1990s and post 2000. The Employment Contracts Act 1991 facilitated a sharp shift from industry and occupational based bargaining to workplace and individualised bargaining, a steep decline in union density and new forms of employee representation (Dannin 1997). There was also a remarkable expansion of individual employee rights in terms of human rights, privacy and personal grievance rights as employment regulation covered all employees (Rasmussen, Hunt and Lamm 2006). As such, the 1990s witnessed a radical shift towards individual employment agreements being the dominant mode. It is also important to stress that the conservative government's anti-union strategy fitted well with a rise in individual employment rights. However, these rights became less popular amongst conservative politicians in the second half of the 1990 s and this approached has continued under the post2008 National-led government (Rasmussen and Anderson 2010).

It is more difficult to explain how individual employment rights have continued to rise under the Labour-led governments in the new millennium. These governments promoted a new form of 'social democracy' with an emphasis on collectivism, public-private collaboration and workplace partnership (Haworth 2004). The new legislative framework - seen as a deliberate attempt to overcome the contractualism and individualism of the Employment Contracts Act (Wilson 2004) - supported explicitly collective bargaining and unionism. This included several measures to bolster unions: better workplace access, exclusive bargaining rights for registered unions, 'good faith' bargaining obligations, and abolishing strike restrictions on multi-employer bargaining. ${ }^{1}$ While union membership has increased in the public sector and while unions have become more visible under the Employment Relations Act, there has been little improvement in overall union density and in the private sector, union density has dropped by $50 \%$ in the new millennium to around $9 \%$ in late 2008 (Blumenfeld 2010).

Why did union density decline in the private sector when the legislation was explicitly (in its objectives and in its intent) supporting collectivism? This is a rather complex issue and it is probably fair to say that no definitive answer has been provided. In an overview of existing research (Rasmussen and Walker 2009: 129-133), it has been suggested that the following explanatory factors have been important:

- employer resistance or lack of support

- employee apathy or lack of interest

- the unions' inability to gain ground on multiemployer collective agreements

- the existence of a 'representation gap'.

Employee apathy or lack of interest is, together with the so-called 'representation gap', areas which need further research (Haynes et al. 2006; Waldegrave et al. 2003). Likewise, Charlwood and Haynes (2008: 104) found - on the basis of analysing the New Zealand Election Study surveys - that 'receding union reach' (ie. a 'representation gap') was a core explanation of union decline during 1990-2002. As this alludes to awards and 'blanket coverage' being abolished by the ECA 1991, this is probably not surprising. However, they also "largely discount structural factors as causes of union decline" (ibid) which, considering that New Zealand has experienced more structural changes than most other OECD countries, is rather surprising and should prompt further research. They also discount employer resistance as a major cause of union decline in New Zealand.

As discussed above, the rise in individual employment rights have undoubtedly had some influence on employee interest in union membership. In the 1990s, the extension of individual employment rights was in line with the government's liberal thinking and anti-union stand. The

\footnotetext{
${ }^{1}$ An overview of the Employment Relations Act, its legislative details and its various impacts have been discussed in four different books: Deeks \& Rasmussen 2002, Rasmussen 2004, Rasmussen 2009, and Rasmussen 2010. These books provide a wide coverage of issues and overviews the diverse opinions of other researchers, though the reader would also need to consult other research publications on more in-depth analyses of specific trends.
} 
Labour-led governments' position is rather more contradictory since employment relations promoted both collectivism and individual employment rights. In fact, the extension of statutory minima was considerable and has changed employment conditions for many people in the lower end of the labour market. This has prompted Rasmussen, Hunt and Lamm (2006) to ask rhetorically why employees should become union members if the main employment gains were provided to government intervention. Again is important to stress there is a lack of research - including the impact of different regulatory approaches (McNeil et al. 2010) - and that the rise in individualism is just one factor amongst many. Likewise, although we focus on employer attitudes in the following, it is important to stress that employer antipathy (or employees' perception of negative employer attitudes) can only be seen as one of several factors in a rather complex decision-making process surrounding collective bargaining and union membership (see Bryson 2008). Still, employer attitudes, behaviour and strategies have become crucial in influencing the employment relations outcomes and processes in New Zealand as employment relations have been decentralised, union presence has declined, and individualised employment arrangements and rights have increased.

\section{Employer attitudes to collective bargaining: survey evidence}

In New Zealand, there has been limited research into the employers' attitudes to collective bargaining or even to employment relations matters in general. The sparse available research indicates, however, that there has been an attitudinal shift in favour of individualism and unitarist employer opinions in the last couple of decades. For example, a 1986 survey found that pluralist ideology was prevalent amongst managers (Geare 1986). Likewise, McAndrew and Hursthouse (1991) concluded that employers preferred national agreements as opposed to enterprise agreements because of the increased costs and greater chances of conflict associated with the latter. It seems obvious to many observers that the Employment Contracts Act has facilitated a stronger employer animosity towards collectivism and this has continued under the Employment Relations Act (Burton 2004, 2010; Foster and Rasmussen 2010). This is also in line with recent surveys of employer attitudes which have concluded that managers have become more unitarist in their opinions about employment relations in their workplaces (Geare, Edgar and McAndrew 2006, 2009). Recent research conducted by the Department of Labour (2009) has further buttressed the idea that employers are quite happy with conducting direct bargaining/negotiations/discussions with their employees but, as a group, they have limited time or trust in unions and collective bargaining. ${ }^{2}$

\footnotetext{
${ }^{2}$ As the Department of Labour (2009) research draws on some of our survey results, it is important to be aware of this when findings are reported. However, the Department of Labour research had a broader focus as it also included focus groups, and interviews with practitioners, employer and union representatives, and academic researchers.
}

On that background, researchers from Massey University and Auckland University of Technology decided to survey employer attitudes to collective bargaining. This would explore how much employer attitudes have shifted since the above mentioned survey of McAndrew and Hurtshouse (1991). It would also investigate whether there are a range of employer attitudes and, if so, what factors are influential in explaining difference.

Three surveys were carried out providing a national coverage of private sector organisations which employed ten or more staff (for a more detailed description, see Cawte 2007; Foster et al. 2009a; Foster and Rasmussen 2010). These were undertaken using a cross-sectional survey design where the surveys matched the sample demographics used by previous New Zealand studies (McAndrew 1989; McAndrew and Hursthouse 1991). It also allowed the entire population of employers $(6800$ individual firms) to be surveyed and covered employers within all seventeen standard industry classifications which had been used by previous researchers (for example, see Blackwood et al. 2007). The three surveys involved a self-administered questionnaire; in two regions (the lower half of the North Island and the South Island) a hard copy was mailed to respondents and in the third region (the upper half of the North Island) an online survey was used. The response rates ranged from a disappointing $8 \%$ for the online survey to $19 \%$ and $21 \%$ respectively for the two postal surveys.

\section{Respondents' attitudes to collective bargaining}

We have discussed findings in our other reports and articles (for references see Foster \& Rasmussen 2010) and in this paper we will focus on two distinct groups of employers. Thus, Table 1 asks: how do the attitudes of employers who are engaged in collective bargaining compare with those employers who are not engaged in collective bargaining? The table highlights those variables that are of significance to employers' attitudes toward the process of collective bargaining (such as, the interest of employees in the process, its relevance to the business, and whether collective bargaining has been considered at all). Taken as a whole, those variables showed marked differences between the two groups of employers. Of those engaged in collective bargaining, only $21 \%$ believed their employees lacked interest in the process. Of those not engaged, the proportion is reversed with $70.1 \%$ arguing that their employees lacked any form of interest in collective bargaining. 


\begin{tabular}{|c|c|c|c|c|c|c|c|}
\hline \multirow{2}{*}{ Variable } & \multicolumn{3}{|c|}{ Engaged in CEA, $\mathbf{n}(\%)$} & \multicolumn{3}{|c|}{ Not engaged in CEA, $n(\%)$} & \multirow{2}{*}{$(P<0.000) \#$} \\
\hline & Agree & Disagree & Unsure & Agree & Disagree & Unsure & \\
\hline $\begin{array}{c}\text { Takes too long to } \\
\text { bargain }\end{array}$ & $127(39.4)$ & $165(51.2)$ & $30(9.3)$ & $265(40.8)$ & $99(15.3)$ & $284(43.8)$ & *** \\
\hline $\begin{array}{c}\text { Transactional costs } \\
\text { too high }\end{array}$ & 101(31.8) & $165(50.1)$ & $51(16.1)$ & $227(35)$ & $81(12.5)$ & $340(52.5)$ & *** \\
\hline $\begin{array}{l}\text { Employees not } \\
\text { interested }\end{array}$ & $67(21)$ & $215(67.2)$ & $38(11.9)$ & $457(70.1)$ & $41(6.2)$ & 154(23.6) & *** \\
\hline $\begin{array}{c}\text { CB not relevant to } \\
\text { business }\end{array}$ & $51(15.9)$ & $252(79)$ & $18(5.6)$ & $487(74.1)$ & $94(14.3)$ & $76(11.6)$ & *** \\
\hline CB never considered & $20(6.2)$ & 292(91) & $9(2.8)$ & $489(74.8)$ & $117(17.9)$ & $48(7.3)$ & $* * *$ \\
\hline $\begin{array}{l}\text { Lack of info on how } \\
\text { to bargain }\end{array}$ & $51(16)$ & $219(68.4)$ & $50(15.6)$ & 214(33.1) & $190(29.4)$ & $243(37.6)$ & *** \\
\hline $\begin{array}{c}\text { Unsure what to } \\
\text { bargain about }\end{array}$ & $16(5)$ & 296(92) & 10(3) & 195(29.9) & $367(56.2)$ & 91(13.9) & $* * *$ \\
\hline $\begin{array}{l}\text { CB adds nothing of } \\
\text { value to business }\end{array}$ & $98(30.5)$ & 183(57) & $40(12.5)$ & $515(78.3)$ & $51(7.7)$ & $92(14)$ & *** \\
\hline $\begin{array}{l}\text { Individual bargaining } \\
\text { offers greater } \\
\text { benefits }\end{array}$ & 152(47.2) & $119(36.8)$ & $51(15.8)$ & $485(73.8)$ & $68(10.4)$ & $104(15.8)$ & 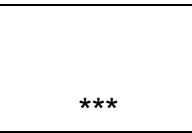 \\
\hline $\begin{array}{l}\text { Unions has never } \\
\text { approached us } \\
\text { about CB }\end{array}$ & $49(15.3)$ & $265(82.8)$ & $6(1.8)$ & $578(87.7)$ & $52(7.9)$ & $29(4.4)$ & *** \\
\hline
\end{tabular}

\# Chi-squared test for differences in more than two proportions. ${ }^{* * *}(\mathrm{P}<0.000)$

These are quite stark differences and ones which were investigated further through the follow-up semi-structured interviews. The differences in employer opinions were confirmed by the interviews, though a strong individual approach clearly prevailed:

"Our staff have had no desire to negotiate collectively. To be honest, the staff are not interested".

"The employees at my place prefer to deal with me face to face rather than being represented by a third party. There is ability for them to discuss their individual performance rather than being locked into a collective agreement".

Differences were found in the proportion of respondents who agreed that collective bargaining was not relevant to their business. Amongst those employers involved in collective bargaining, $15.9 \%$ agreed that it was not relevant to their business versus $74.1 \%$ amongst those not involved. In the interviews, some employers involved in collective bargaining found that it was not relevant because of the quality of the relationship with the union or because the workplace had no major problems (according to the manager). These were typical comments:

\begin{abstract}
"With our current one I wouldn't say that it offers any benefits or is of relevance. I believe that if you have a good union who works with you in partnership then it can be very productive".

"I just honestly see no value - we don't have employment disputes. It's a happy workplace”.
\end{abstract}

Further strong differences were found when employers were asked if they had considered engaging in collective bargaining, with $74.8 \%$ of non-involved employers having never done so as against $6.2 \%$ of involved employers.

It is interesting to note that some employers (30\%) involved in collective bargaining agreed with the point that individual bargaining offers greater benefit. This implies that those employers would probably prefer individualised bargaining but it is not a realistic option for them at the moment. This stance also featured strongly in the interviews. Here is a typical example of opinion amongst those employers involved in collective bargaining but who consider that individual bargaining offers greater benefit:

"I don't think they got anything through collective bargaining that we would not have if they were on individual agreements. We only go through the motions as the ERA requires us to negotiate with the union". 
In the interviews, a number of employers involved in collective bargaining also felt that collective bargaining encouraged mediocrity:

I think as far as all the issued stuff they get, like boots, gear and that, should all be in a collective employment agreement, but as far as wages go, some of our guys really deserve a pay rise and some don't. With collective bargaining, then they all get it. Some people you would love to give a rise, others you don't. I think wages should be on an individual basis.

However, $57 \%$ of employers involved in collective bargaining disagreed that collective bargaining would add nothing of value to the business. From the interviews it would appear that this was particularly the position amongst employers who have a good working relationship with the union (or unions). These are typical responses amongst employers who think that collective bargaining can add something of value to their business:

"The whole process of the agreements is a lot quicker and lot smoother. We like to have union involvement".

"The benefits of collective bargaining for us are that it is easier to manage with one package".

Finally, those involved in collective bargaining found that the transactional costs were high (50.1\% agreed). This was the overwhelming case across all employers and it was strongly expressed in the semi-structured interviews. As one employer said:

"There is a huge cost in the bargaining process. Our team consists of the HR manager and advisor, chief commercial officer and an EMA [Employers and Manufacturers Association] person. It costs us lost wages and time and the administration process of costing out the claims is considerable".

Overall, it is important to note that the employers who are engaged in collective bargaining constitute a clear minority and even amongst these employers there is criticism of bargaining processes and associated outcomes. Generally, employers have a negative attitude towards collective bargaining and unionism and they would prefer to conduct their employment relations affairs in direct discussion with individual employees.

\section{The long-standing issue of low productivity growth}

Comparatively slow productivity growth has been a longstanding problem in New Zealand, refer to Figure 1. From having one of the highest living standards (measured in gross domestic product per head) in the 1950 s it has recorded a persistent relative decline and is currently being ranged below number 20 amongst OECD countries. This relatively decline has influenced the socalled New Zealand 'experiment' and has prompted radical public policy changes. The decline has also influenced the thinking behind employment relations reforms. The Employment Contracts Act tried to create an 'efficient labour market' through facilitating employerdriven flexibility and the Employment Relations Act sought to facilitate 'productive employment relationships'. Neither of these legislative frameworks has brought about the anticipated improvements in productivity growth. It is still debated in New Zealand why and to what degree this has happened (see Haworth 2010; Rasmussen 2009: 447-455). In case of the Employment Contract Act, it has been suggested that the policy prescription may have been wrong and/or the context was not supportive enough (for example, in terms of infrastructure investments). In case of the Employment Relations Act, the emphasis on collectivism and collaboration did not manifest itself and there was considerable catch-up investment in, for example, infrastructure, education and social problems. However, some commentators - including many employer organisations - have also disputed the employment relations approach.

Whatever the explanations, the comparative decline in living standard and productivity growth has now become a mainstay of news reports. As shown below, employment relations has temporarily regained its high profile role and are likely to be a major issue in the 2011 general election. Still, there can be doubts whether the current employment relations approach is putting New Zealand on the track towards a more productive economy and thus breaking the relative economic decline seen in Figure 1. 


\section{Figure 1.}

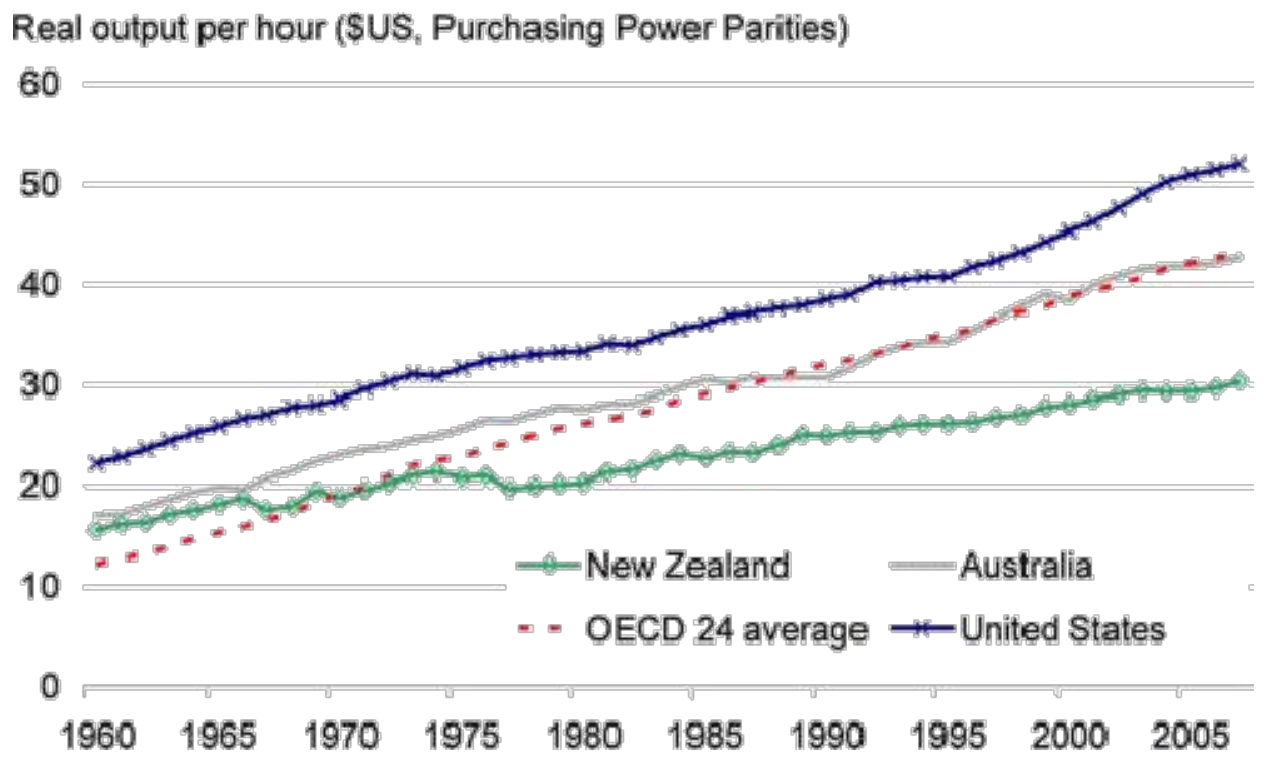

Source: Treasury, 2008

Can individualism be aligned with a productive, high-wage, high-skill economy?

The leading employer organisation - Business New Zealand - has clearly voiced the employer opposition to many of the employment relations changes under the Labour-led government. This has been supported by various other employer organisations and 'think tanks', including the high-powered Business Roundtable. For example, in response to New Zealand's lowest growth in productivity in 31 years, Business New Zealand argued in a press release that New Zealand should implement a Productivity Commission (as in Australia) and needed "things like more flexible employment law, lower taxes and a smaller compliance burden..." (Business NZ 2010). These arguments are in line with Business New Zealand's briefing to incoming government in 2008 where it advocated more flexibility and freedom in the workplace. There appears to be two problems with this argument: first, it is difficult to associate the higher Australian productivity growth with 'flexible employment law, lower taxes and a smaller compliance burden'. Second, the implied suggestion that a re-regulation towards individualism may encourage greater competitive flexibility and innovation would need to await a final evaluation of the productivity experience of the 1990s so far seen as insufficient by many researchers - where employers had a remarkable free hand in terms of establishing their preferred working arrangements (see Boxall 1997, Deeks \& Rasmussen 2004: 165-169). Instead we suggest another view below.

It is unclear how employer preferences for workplace and individualised employment can be part of a successful attempt to build a sustainable route to a high-wage, highskill economy. As discussed below, there seems to be at least three types of issues associated with this approach.

- There are few industries which have shown substantial growth recently and arguably too few industry-level collaborative solutions exist which can establish a sustainable economic growth path.

- There is a distinct lack of a broadly based 'plan' of how to inform and persuade employers to adopt more productive employment relations approaches.

- Employer aversion to mandatory minima and/or collectively agreed minima facilitates a low cost, low skill 'equilibrium' where mainstream employers have to compete with employers who have rockbottom employment conditions and invest little in their staff.

Under the Labour-led governments a number of initiatives were taken to developed industry growth paths and there was direct support for several 'sunrise industries' (Haworth 2010). These efforts have had some success but they were limited in funding and coverage and have had insufficient impact across the economy. While employer organisations have been involved in some of these initiatives, their main focus has been on the training and development area. Even in the latter area there appears to be ample room for improvement. This has been illustrated by wide-ranging skill shortages and concerns about the propensity to 'free-ride' amongst small and medium sized employers. In a survey of employers' perspectives on skill shortages, Baron and McLaren (2006) found that employers were openly pessimistic about the prospects of any improvement in the supply of skilled labour (especially qualified trades people) over the medium to long-term future. 
Importantly, Baron and McLaren found that employers were split on how to rectify the situation. Employer opinions ranged from suggesting a more active role, supporting existing vocational training schemes or expressing support for the old industry training system that was disestablished in the early 1990s. And this doesn't allude to the underlying problem: many employers do not invest in vocational training or have well-defined career paths (Hunt and Rasmussen 2007; Williamson et al. 2008). It is unclear how an individualised approach will deal with this problem, especially in light of the prevalence of small and medium size firms.

Second, there is a distinct lack of a broadly based 'plan' of how to inform, persuade and make it easy and cost effective for employers to adopt more productive employment relations approaches. Again, the many small and medium sized businesses constitute a thorny problem. This is despite that this is an area where there has been considerable effort in the new millennium. Employer organisations have been active in their provision of information and services. They have also been involved in and supportive of government initiatives (Burton 2010). For example, Department of Labour now has a raft of on-line information and application options, there have been a string of workplace 'demonstration case studies', the Partnership Resource Centre and Workplace Productivity Group have promoted workplace change initiatives (see Haworth 2010). Still, there appears again to be ample room for improvement. In the survey of employer opinions discussed above, we asked employers about the quality of information and the practical value of the information on collective bargaining and good faith which they received from their business organisations. The majority of respondents found the information either poor $(25.4 \%)$ or just adequate $(38.8 \%)$. We also asked employers what they thought of the advice from government and the results were similar. Interesting, there was greater concern amongst small to medium sized enterprises than amongst larger organisations. As larger organisations will often have specialist staff or can afford consultants who can advise them, this again leaves the many small and medium sized employers in the lurch. If these employers are not receiving good advice then what do they do?

Third, the preference for workplace and individualised employment arrangements and, in particular the constant criticism of statutory minima changes, opens the gate for low paying and low productivity employers (as McLaughlin (2010) has argued). This has clearly been the trend under the post-2008 National-led government (see below), where both collective and individual employment rights have been seen as barriers to more 'flexible' employment arrangements. It is puzzling that there has been pressure from employer organisations to reduce employment standards as this makes it easier for mainstream employers to being undercut by 'cheap labour' employers. If neither collective bargaining nor statutory minima are seen as suitable ways of lifting employment standards then higher employment standards can only happen through employer competition for staff. Although such competition has been driving up employment conditions in the new millennium (until the post-2008 economic crisis) it has also been associated with labour market 'bottlenecks' and insufficient productivity improvements. This is exactly the 'low skill, low wage equilibrium' that McLaughlin (2010) talks about. Again, it is difficult to see how such an approach can establish a sustainable basis for the elusive high skill, high wage economy.

\section{Where to now?}

In late 2008 , there was a political power shift when a National-led government gained office. Interestingly, employment relations was hardly discussed and the National Party announced explicitly that it would keep the Employment Relations Act though with some modifications.

However, it has been suggested that "the National Party's policy would involve considerable change to the existing public policy platform." (Rasmussen and Walker 2009: $168)^{3}$ as it would seek to implement the following changes:

- Removing the union monopoly bargaining rights for collective agreements, to allow non-union workers to enter into collective agreements;

- Reviewing personal grievance procedures;

- Introducing an optional 'probationary period', where new employees would not have access to personal grievance provisions;

- Reducing compliance costs, and in particular, removing ACC's monopoly over workplace injury insurance;

- Revisiting the Holidays Act.

Some of these changes have already been implemented, some of them are still being considered and further changes have started to be discussed. Most of the changes point in the opposite direction to a high-wage, high-skill economy. For example, are reducing statutory minima the way to encourage employers to improve wages and other employment conditions? It also appears a short-term solution to allow people to 'sell' one week of annual leave when most people only have 4 weeks annual leave entitlements and when long working hours have become a well-recognised problem (Callister 2005). As Rasmussen and Anderson (2010) have illustrated, there are clear links to the defunct policies of the 1990s. The main difference is that the envisaged changes are less of a frontal attack on collective bargaining, unions and employee conditions, compared to the policies of the 1990s. The main issue in connection with this paper is, however, that long-term productivity benefits can be hard to envisage and so can the link to a high-wage, high-skill economy.

Following the government's announcement of 32 proposed policy changes in August 2010, employment

\footnotetext{
${ }^{3}$ The importance of these changes has been debated in New Zealand with some researchers arguing that the current government's labour law reform is not that substantive (see eg. Hodge 2010).
} 
relations has once again a high profile in the public policy debate (Haworth 2010b, Hodge 2010, Kay 2010). Still, there are few public policy analyses which link employment relations changes to the wider economic debate about New Zealand's relative decline (though see Haworth 2010b). Although there have been several recent reports addressing New Zealand's economic issues, they have totally bypassed the influence - positively or negatively - of employment relations. While the Employment Contract Act heralded increased labour market flexibility as a route towards a more 'efficient labour market' and the Employment Relations Act saw collectivism and better protections and processes as a way forward towards 'productive employment relationships', there are no similar aspirations associated with recent changes. They are piecemeal attempts to deal with specific issues and hopefully generate some immediate economic gains through providing employer cost relief.

\section{Conclusion}

The rise in individualism and workplace bargaining has coincided with growing concerns over disappointing productivity growth and that combination has had a major impact on public policy debate in New Zealand. There have been serious attempts of path-breaking in respect of employment relations and this has happened to a large degree. As shown, the regulatory framework, the institutional setting (including collective bargaining) and the attitudes and behaviours of the key players have shifted considerably in a matter of two or three decades. As such, the New Zealand 'experiment' in employment relations changes is of comparative interest if one is interested in traditional employment relations research areas: employment regulation, union renewal, employer attitudes and strategies, protection of employee rights, employee influence and participation, high performance work systems, etc.

However, it is still unclear how the on-going shift towards workplace and individual bargaining can be aligned with the aspirations of higher productivity growth. As New Zealand lacks major industrial giants (except in the dairy industry), there are few strong firms or industries which can establish sufficient strong leadership in terms of economic growth and productive work practices. Even in the area of vocational training, where the employer organisations have voiced a strong support, has the efforts fallen short and it is highly likely that a new economic upswing will feature skill shortages. New Zealand appear trapped in a 'low skill, low wage equilibrium' and this is further aggravated by a latent 'brain drain' of highly educated people because of the comparatively low wages in New Zealand.

The recent public policy debate in New Zealand is also interesting because of the current peripheral position of employment relations when it comes to tackling the longstanding issue of insufficient productivity growth; employment relations is seen neither as a problem nor as a solution. The public policy debate is focusing on major contextual changes - such a tax reform, export incentives or supporting sharemarket expansion - while employment relations reform has become very piecemeal (targeting specific areas) and relatively narrow with an emphasis on employer 'flexibility' in terms of reducing individual employment rights. Besides a near-certain reduction in employment standards, it has been suggested that it is unlikely that this will generate significant productivity enhancing incentives for individual employers.

\section{References}

Baron, P. and McLaren, E. 2006 Overcoming Skill Shortages: Employer Perspectives and Strategies. Research Report, Auckland, Labour Dynamic Research Programmes, Massey University.

Blackwood, L., Feinberg-Daneili, G., Lafferty,G., O'Neil, P., Bryson, J. and Kiely, K.. 2007. Employment Agreements: Bargaining Trends and Employment Law Update 2006/2007. Industrial Relations Centre, Victoria University, Wellington.

Blumenfeld, S. 2010. 'Collective bargaining.' In Rasmussen, E. (ed.), Employment Relationships: Workers, Unions and Employers in New Zealand. Auckland University Press, Auckland.

Boxall, P. 1997. 'Models of employment and labour productivity in New Zealand: an interpretation of change since the Employment Contracts Act.' New Zealand Journal of Industrial Relations, 22(1): 2236.

Bryson, A. 2008. 'Union Free-riding in Britain and New Zealand.' Journal of Industrial Relations, 50(1): 524.

Burton, Barbara. 2004. 'The Employment Relations Act according to Business New Zealand.' In Rasmussen, E. (ed.), Employment Relationships: New Zealand's Employment Relations Act. Auckland University Press, Auckland.

Burton, Barbara. 2010. 'Employment relations 20002008: An employer view.' In Rasmussen, E. (ed.), Employment Relationships: Workers, Unions and Employers in New Zealand. Auckland University Press, Auckland.

Business New 2010. www.businessnz.org.nz/doc/1854/Poorproductivit ystatsshowneedforProductivityCommission

Callister, P. 2005. 'Changes in paid working hours for couples, 1986-2001.' New Zealand Journal of Employment Relations, 30(2): 51-64.

Cawte, T. 2007. Employers Attitudes Toward Collective Bargaining: a Comparative Study. Honours Degree Dissertation. Massey University, Palmerston North. 
Charlwood, A. and Haynes, P. 2008. 'Union Membership Decline in New Zealand, 1990-2002.' Journal of Industrial Relations, 50(1): 87-110.

Dalziel, P. and Lattimore, R. 1999. The New Zealand Macroeconomy: A Briefing on the Reforms. Oxford University Press, Auckland.

Dannin, E. 1997. Working Free: the Origins and Impact of New Zealand's Employment Contracts Act. Auckland University Press, Auckland.

Deeks, J. and Rasmussen, E. 2002. Employment Relations in New Zealand. Pearson Education New Zealand, Auckland.

Department of Labour. 2009. The Effect of the Employment Relations Act 2000 on Collective Bargaining. Department of Labour, Wellington. (www.dol.govt.nz)

Foster, B., Murrie, J. and Laird, I. 2009a. 'It takes two to tango: evidence of a decline in institutional industrial relations in New Zealand.' Employee Relations, 31(5): 503-514.

Foster, B., Rasmussen, E., Laird, I. and Murrie, J. 2009b. 'Employer attitudes toward collective bargaining: Surveys of employers' role and attitudes in New Zealand.' Paper, 15th IIRA World, Sydney, August 2009. (On CD - ISBN 978-0-9806755-1-1).

Foster, B. and Rasmussen, E. 2010. 'Employer attitudes to collective bargaining.' In Rasmussen, E. (ed.), Employment Relationships. Workers, Unions and Employers in New Zealand. Auckland University Press, Auckland.

Geare, A. 1986. 'An Examination of Certain Aspects of Industrial Relations Ideologies:

A Theoretical Analysis and an Empirical Study', PhD thesis 87 30270, New Zealand: University of Otago.

Geare, A., Edgar, F. and McAndrew, I. 2006. 'Employment Relations: Ideology and HRM Practice.' International Journal of Human Resource Management, 17(7): 1190-1208.

Geare, Alan, Fiona Edgar and Ian McAndrew. 2009. "Workplace values and beliefs: an empirical study of ideology, high commitment and unionisation." International Journal of Human Resource Management, Vol. 20, No. 5, pp. 1146-1171.

Haworth, N. 2004. 'Beyond the Employment Relations Act: the wider agenda for employment and social equity in New Zealand.' In Rasmussen, E. (ed.), Employment Relationship: New Zealand's
Employment Relations Act. Auckland University Press, Auckland.

Haworth, N. 2010. 'Economic transformation, productivity and employment relations in New Zealand 1999-2008.' In Rasmussen, E. (ed.), Employment Relationships. Workers, Unions and Employers in New Zealand. Auckland University Press, Auckland.

Haworth, N. 2010b. ''Fire at will' measure damaging to labour performance and economy.' Sunday StarTimes, 29 August 2010, p. A6.

Haworth, N., Hughes, S. and Wilkinson, R. 2005. 'The international labour standards regime: a case study in global regulation.' Environment and Planning A, 37: 1939-1953.

Haynes, P., Boxall, P. and Macky, K. 2006. 'Union reach, the 'representation gap' and the prospects for unionism in New Zealand.' Journal of Industrial Relations, 48(2): 193-216.

Hodge, B. 2010. 'What's all the fuss about the 90-day trial period?' Sunday Star-Times, 22 August 2010, p. A6.

Hunt, V. and Rasmussen, E. 2007. 'Turnover and retention in a tight labour market: reflecting on New Zealand research.' New Zealand Journal of Employment Relations, 32(1): 45-58.

Kay, M. '90-day trial of union muscle.' Dominion Post, 14 August 2010, p. B3.

Kelsey, J. 1997. The New Zealand Experiment. Auckland University Press, Auckland

Kochan, T., McKersie, R.D. and Cappelli, P. 1984. 'Strategic Choice and Industrial Relations Theory.' Industrial Relations, 23(1):16-39.

McAndrew, I. 1989. "Bargaining Structure and Bargaining Scope in New Zealand: the climate of employer opinion", New Zealand Journal of Industrial Relations, 14: 133-148.

McAndrew, I. and Hursthouse, P. 1991. 'Reforming Labour Relations: what southern employers say.' New Zealand Journal of Industrial Relations, 16(1): 1-11.

McLaughlin, C. 2010. 'Building a 'high road' economy? The Employment Relations Act in an international comparative perspective.' In Rasmussen, E. (ed.), Employment Relationships. Workers, Unions and Employers in New Zealand. Auckland University Press, Auckland. 
McNeil, J., Haworth, N. and Rasmussen, E. 2010. Addressing the productivity challenge? Government-sponsored partnership programs in Australia and New Zealand. Paper, Newcastle University, Australia, March 2010.

Rasmussen, E. (ed.). Employment Relationship: New Zealand's Employment Relations Act. Auckland University Press, Auckland.

Rasmussen, E. 2009. Employment Relations in New Zealand. Pearson Education, Auckland.

Rasmussen, E. (ed.). Employment Relationships. Workers, Unions and Employers in New Zealand. Auckland University Press, Auckland.

Rasmussen, E. and Anderson, D. 2010. 'Between unfinished business and an uncertain future.' In Rasmussen, E. (ed). Employment Relationships. Workers, Unions and Employers in New Zealand. Auckland University Press, Auckland.

Rasmussen, E. and Walker, B. 2009. 'Employment relations in the millennium.' In Rasmussen, E. 2009. Employment Relations in New Zealand. Pearson Education, Auckland.

Standing, G. 2008. 'The ILO: An Agency for Globalization?' Development and Change, 39(3): 355-384.

Waldegrave, T., Anderson, D. and Wong, K. 2003. Evaluations of the short term impacts of the Employment Relations Act 2000. Department of Labour, Wellington.

Williamson, D., Harris, C. and Parker, J. 2008. 'I love you - goodbye: Exit Interviews and Turnover in the New Zealand Hotel Industry.' New Zealand Journal of Employment Relations, 33(3): 70-90.

Wilson, M. 2004. 'The Employment Relations Act: a framework for fairer way.' In Rasmussen, E. (ed.), Employment Relationship: New Zealand's Employment Relations Act. Auckland University Press, Auckland. 